Вісник Дніпропетровського університету. Серія: геологія, географія. 2016. 24 (1), 112-119.

Vìsnik Dnìpropetrovs'kogo unìversitetu. Seriâ geologiâ, geographîa

Dnipropetrovsk University Bulletin. Series geology, geography. 2016, 24 (1), 112-119.

doi: $10.15421 / 111617$

http://geology-dnu.dp.ua

УДК 911.3:332.2 (477.82)

\title{
Селітебні ландшафти в структурі угідь височинної області Волині
}

\author{
О. О. Ничая, Н. А. Тарасюк \\ Східноєвопейський національний університет імені Лесі Українки, Луцьк, Украӥна, \\ e-mail:sasha.ni4aya@yandex.ua; nina_tarasiuk@ukr.net
}

\begin{abstract}
Відображено результати оцінювання особливостей сучасного селитебного землекористування для території височини в межах Волинської області. Динаміка структури земельного фонду Волині характеризується інтенсивним збільшенням площі забудованих земель, тобто власне селитебних ландшафтів.

Селитебно-забудовані ландшафти представлено в розрізі адміністративно-територіального поділу. Для характеристики забудованих земель Волинської височини опрацьовано дані по території Горохівського та Ківерцівського районів, 3 виділеними ключовими ділянками КД-5 та КД-6. Установлено частку забудованих земель у структурі земельних угідь, складено матриці комплексів використання селитебно-забудованих ландшафтів. На основі аналізу побудовано цифрову векторну модель. Установлено зміну площі селитебного ландшафту та його рисунка впродовж століття. 3 метою оцінювання сучасного стану природокористування території визначено частку земель селитебно-житлової забудови в загальній площі забудованих територій.
\end{abstract}

Ключові слова: забудовані землі, рисунок ландмафту, природокористування, селитебно-забудовані землі, селитебно-житлова забудова, иифрова векторна модель

\section{The inhabited landscapes in the land structure of Volyn region upland area}

\author{
O. O. Nychaia, N. A. Tarasiuk \\ Lesya Ukrainka Eastern European National University, Lutsk, Ukraine, \\ e-mail:sasha.ni4aya@yandex.ua; nina_tarasiuk@ukr.net
}

The article presented the assessment results of modern inhabited land utilization in the entire upland territory within Volyn region. Dynamics of the available land structure in Volyn is marked by extreme increase in built-up area that is inhabited landscape itself.

Inhabited built-up landscapes are represented in the context of the administrative and territorial division. In order to characterize built-up land in upland area of Volyn region the data from the territories of Gorohiv and Kivertsi districts were processed with singled out key areas KA -5 and KA -6. The share of built-up land in the structure of land was determined, the moulds of inhabited built-up landscapes usage were composed. Basing on the space photos and topographical maps analysis the digital vectorial model of inhabited development dynamics was constructed. Area alterations in inhabited landscape and its pattern during the century were established. For the purpose of modern nature management assessment of the territory the share of inhabited built-up development in the total area of development was determined. A number of map charts, diagrams and tables was constructed according to the results of the research work. Subsequent directions of inhabited landscapes geoecological rehabilitation were confirmed in terms of regional development.

Key words: built-up landscapes, pattern of the landscape, nature management, inhabited built-up landscapes, digital vectorial model

Постановка проблеми у загальному вигляді. Сучасний науково-технічний розвиток відкриває все ширші можливості ефективного використання природних ресурсів для потреб розвитку господарства, населених пунктів, інфраструктури. Одночасно із цим відбуваються значні стійкі зміни природного середовища, збільшується частка антропоген- них комплексів, що має негативні наслідки. Так, несприятливі побічні явища у системі взаємовідносин «людина-природа» можуть викликати серйозні порушення природно-просторової структури, в результаті чого погіршуються екологічні умови середовища життя людини. Тому характеристика й оцінка змін ландшафтної структури сприятимуть оптимізації 
природокористування, що є одним із пріоритетних напрямів дослідження для забезпечення стійкого розвитку регіону.

Волинська область цікава значним ландшафтним різноманіттям. Упродовж тривалого історичного періоду спостерігаємо збільшення частки забудованих територій, а саме селитебних ландшафтів. Природні умови, види та напрями природокористування відображені не тільки в динаміці, структурі ландшафтної будови, а і в сучасному рисунку ландшафту. Тому, вивчення просторово-часових змін поширення селитебної забудови в межах Волинської височини є однією зі складових комплексної оцінки території для потреб територіального розвитку.

Аналіз останніх досліджень і публікацій. Проблеми сучасного землекористування проаналізовані в науковому доробку багатьох дослідників, як географів, так і аграріїв (Darchuk, 2011; Kovalchuk, et al. 2015; Pavlovska, 2014; Ryhter, G. 1983; Suhyj, P. 2007; Tarasjuk \& Nychaja, 2015; Tarasiuk \& Nychaja, 2014). Увага до вивчення земельних ресурсів та їх структури зумовлена, передусім, тим, що саме земля в Україні є найбільшим багатством, а тривалий період використання цього ресурсу вносить значні зміни в його якісні характеристики. У працях П. О. Сухого (2007), А. Я. Сохнича (2001), Д. С. Добряка (2001), Л. Я. Новаковського (2001), І. П. Ковальчука (2015), Г. Д. Гуцуляка (1991), М. Д. Заячука (2005) наведено результати аналізу та оцінювання стану земельних ресурсів, акцентовано увагу на сучасних проблемах землекористування з позицій розвитку сільського господарства та інфраструктури (Darchuk, 2011); Kovalchuk, et al. 2015); Suhyj, 2007).

Регіональні аспекти землекористування в межах Волинської області висвітлено у працях А. М. Шворак (2001, 2014), Т. С. Павловської (2014), Р. М. Панаса (2011). Раз ом $з$ тим, питання оцінки селитебного землекористування на території волинської області залишається недостатньо вивченим. Проте селитебні ландшафти були і залишаються основним осередком впливу на стан довкілля.

Роль селитебних ландшафтів у формуванні сучасної структури землекористування регіонів розглядається в публікаціях Л. І. Воропай та М. М. Куниці (1982), Г. І. Денисика (1998, 2006, 2012) та його ландшафтної школи - приміські ландшафти Східного Поділля (О. І. Бабчинська, 2006), сільські селитебні ландшафти Поділля (А. Г. Кізюн, 2012). Екологічний стан урболандшафтів Волинської області висвітлили М. І. Лепкий (2003) та В. О. Фесюк (2003).
Сучасні IT-технології відкривають нові можливості для дослідження та моніторингу стану довкілля. Застосування ГІС-технологій для практики природокористування описані в наукових періодичних виданнях та електронному ресурсі (Malchykova, 2010; Shvorak, 2001).

Мета та завдання статті. Мета статті - аналіз структури селитебного землекористування височинної території Волинської області для вирішення завдань оптимізації природокористування в районному плануванні та для потреб геоекологічної реабілітації селитебних ландшафтів регіону.

Поставлена мета зумовлює виконання таких завдань: охарактеризувати особливості динаміки забудованих земель височинної території Волинської області; дослідити компонентну структуру селитебно-забудованих земель; проаналізувати динаміку площі та рисунка селитебного ландшафту; виділити своєрідність використання селитебно-забудованих земель на регіональному рівні.

Матеріали й методи дослідження. Інформаційною базою дослідження слугували вихідні дані Головного управління статистики Держземагентства у Волинській області (форма 6-зем), комплект топокарт Генштабу (масштабу 1:100 000 за період з 1973 по 1989 рр.); за період з 1925 по 1933 рр. - карти такого ж масштабу Wojsrjwy Instytut Geograficzny Warszawa; 1910 p. - K. u. K. Militärgeographisches Institut, Wiedeń, масштабу 1:75 000), цифрова топокарта Волинської області, інтернет-ресурси (Retrieved from http://zem. voladm.gov.ua; http://www.google.com.ua/intl/ru/earth).

За допомогою сучасних IT-технологій (MapInfo Professional 11.0.3, Google Earth та CorelDRAW X5) побудовано картосхеми та цифрову векторну модель динаміки забудови селитебних земель. Крім методу картографічного моделювання, застосовуємо метод ключових ділянок (метод ключів). Аналіз динаміки селитебної забудови та ландшафтного рисунка здійснюємо за допомогою ретроспективно-географічного методу, порівняльно-географічного, математичного, статистичного, графічного, метод аналізу та синтезу.

Виклад основного матеріалу й обгрунтування отриманих результатів дослідження. Забудованими землями називають ті, на яких розташовані будівлі, споруди, подвір'я, вулиці, площі і які характеризуються як селитебні ландшафти (Litynskyj, V. 2001).

У структурі сучасного землекористування Волинської області, за даними Головного управління статистики Держкомзему у Волинській області станом на 01.01.2015 р., забудовані землі, займають $3 \%$ території області (Darchuk, 2011). Це один iз 
найскладніших та найбільш інтенсивно зростаючих за площею різновид антропогенних ландшафтів. Динаміку площі забудованих земель Волинської області (за період 2000-2015 рр.) наведено на рисунку 1.

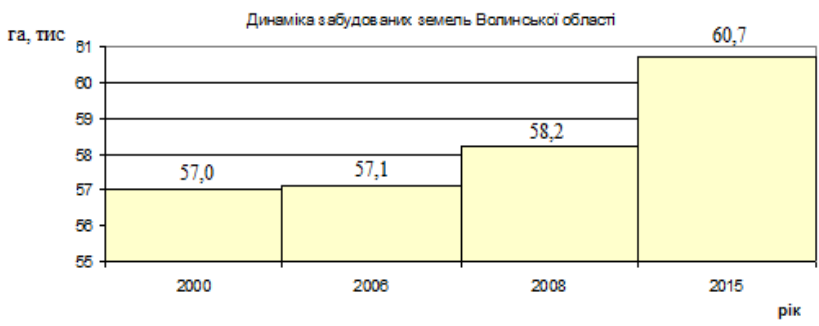

Рис. 1. Динаміка забудованих земель Волинської області

Проте селитебно-забудовані землі досить відмінні за функціями. Різновиди забудови зумовлені функціональним призначенням, і серед селитебнозабудованих земель можемо виокремити їх групи:

селитебно-житлова забудова (будинки садибної та несадибної забудови, садові та дачні будинки);

селитебно-рекреаційна забудова (зелені насадження, вулиці, площі, набережні, стадіони, бази відпочинку, санаторії, кемпінги, наметові містечка);

селитебно-сакральна забудова (церкви, кладовища, монастирі, пам'ятки); селитебна інфраструктура (громадсько-технічна селитебна забудова, комерційно-селитебна забудова, сільськогосподарська та лісогосподарська виробничо-селитебна забудова, промислово-селитебна забудова, транспортно-селитебна забудова);

селитебна забудова змішаного використання і бедленду (Tarasjuk \& Nychaja, 2015).

Ці групи забудованих земель ми розглядаємо як функціональні типи селитебних ландшафтів. Але в межах Волині є суттєві відмінності, зумовлені традиціями природокористування в поліській i височинній області.

У попередніх публікаціях було проаналізовано особливості селитебної забудови для території Полісся Волинської області (Tarasjuk \& Nychaja, 2015). Територія височинної області Волині характеризується своєрідністю типів сільських забудованих земель, що визначається особливостями рельєфу та збільшенням площі земель, які обробляються.

Територіальну диференціацію забудови здійснюємо на адміністративному мікрорівні (міські, селищні, сільські ради) з виділенням ключових ділянок (КД). Для аналізу селитебно-забудованих ландшафтів височинної території Волині опрацьовано дані за двома ключовими ділянками КД-5 та КД-6 (рис. 2).

Дослідження проведено в межах двох височинних територій - Горохівського (КД-5 - Печихвостівська

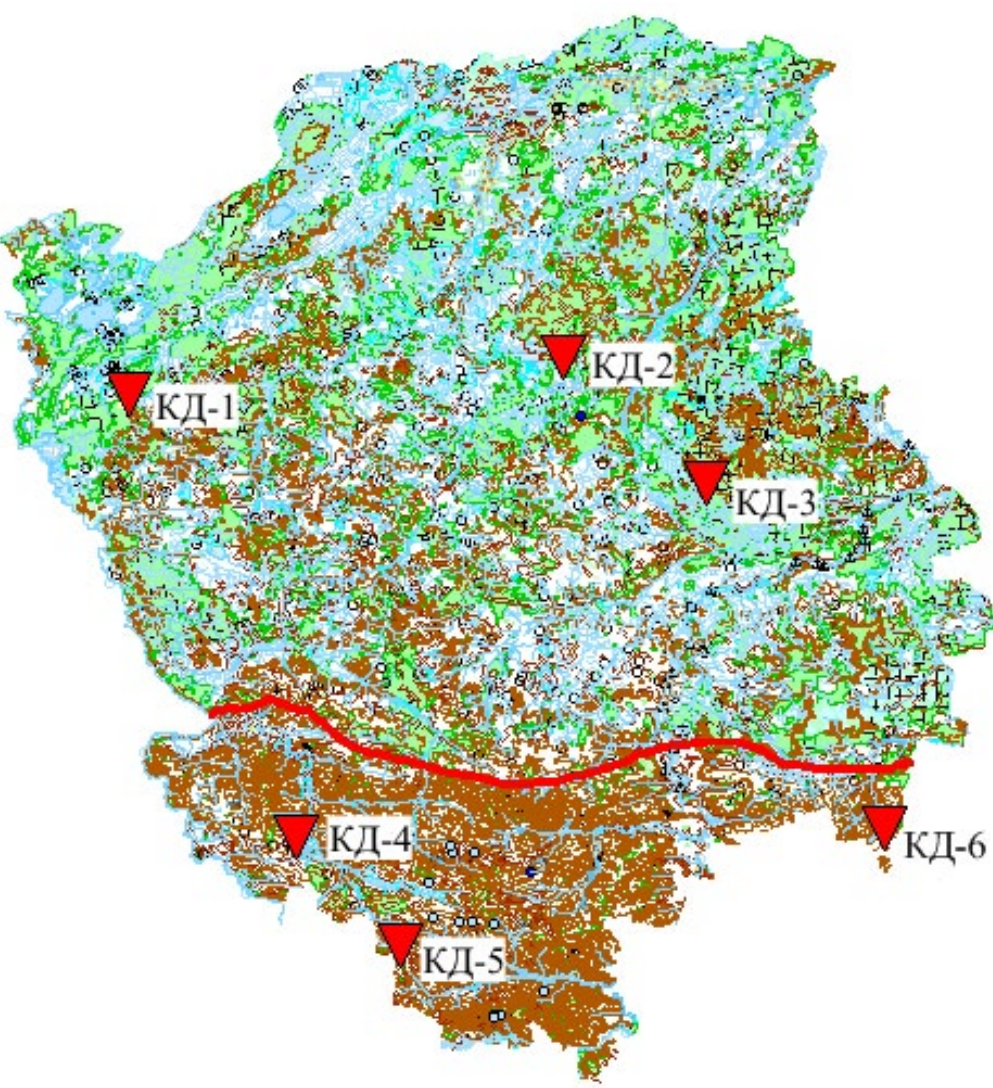

Умовні позначення:

межа фізико-географічних областей

ключова ділянка (КД)

Рис. 2. Ключові ділянки (КД) в межах фізико-географічних областей Полісся і Волинської височини 
c/p) та Ківерцівського (КД-6 - Олицька с/p) районів. Частка забудованих земель для території Горохівського району становить 4,1%, а для Ківерцівського - 3,6 \%. Найбільш забудовані території - це міста та селища міського типу: м. Горохів (69\%), м. Берестечко $(51,5 \%)$, смт. Мар'янівка (61,2 \%), смт. Сенчеківка $(36,4 \%)$ - Горохівський район та м. Ківерці $(22,8$ \%) - Ківерцівський район.

Серед сільських рад найбільше забудовані Бужанівська (14,7\%) та Лемечівська (8,08 \%), Цегівська (7,5 \%) c/p Горохівського району та Жидичівська (16,5 \%), Дернівська (11,2%) c/p Ківерцівського p-ну. Високими показниками характеризуються Губинська $(5,3 \%)$, Рачинська (4,8 \%) (Горохівський район) та Прилуцька (7,3 \%), Цуманська (6,5%) (Ківерцівський р-н). Серед сільських рад із найменшою часткою забудови виділяються Бережанська (1,5 \%), Мирнівська (1,5%), Михлинська (1,6 \%) сільські ради Горохівського району та Берестянська $(1,2 \%)$, Макаревичівська (1,5\%) Сокиричівська (1,5 \%), Суська (1,5\%) сільські ради Ківерцівського району (рис. 3). рад частка забудованих земель значно відрізняється від середньозваженого показника по району і області (табл. 1). Очевидно, що важливим чинником є сучасна інфраструктура району та області, що проявляється не лише в зручності географічного положення, а i в особливостях транспортної мережі.

На місцевості природно-територіальна структура виражається у структурі землекористування, під якою слід розуміти структуру використаних площ у поєднанні з функціональними особливостями. Структура землекористування тривимірна. Тому структура селитебних ландшафтів відмінна за просторовими площинними показниками і вертикальною ярусністю. У селитебних ландшафтах багато об'єктів, подібно до основного ярусу, можуть займати також простір вище і нижче поверхні землі. Ми розглядаємо відмінності площинної (горизонтальної) структури селитебних ландшафтів.

Кожному виду землекористування відповідає власна сформована просторова структура. Особливо вона помітна в населених пунктах - селитебно-забудованих ландшафтах, де проявляється в конфігурації

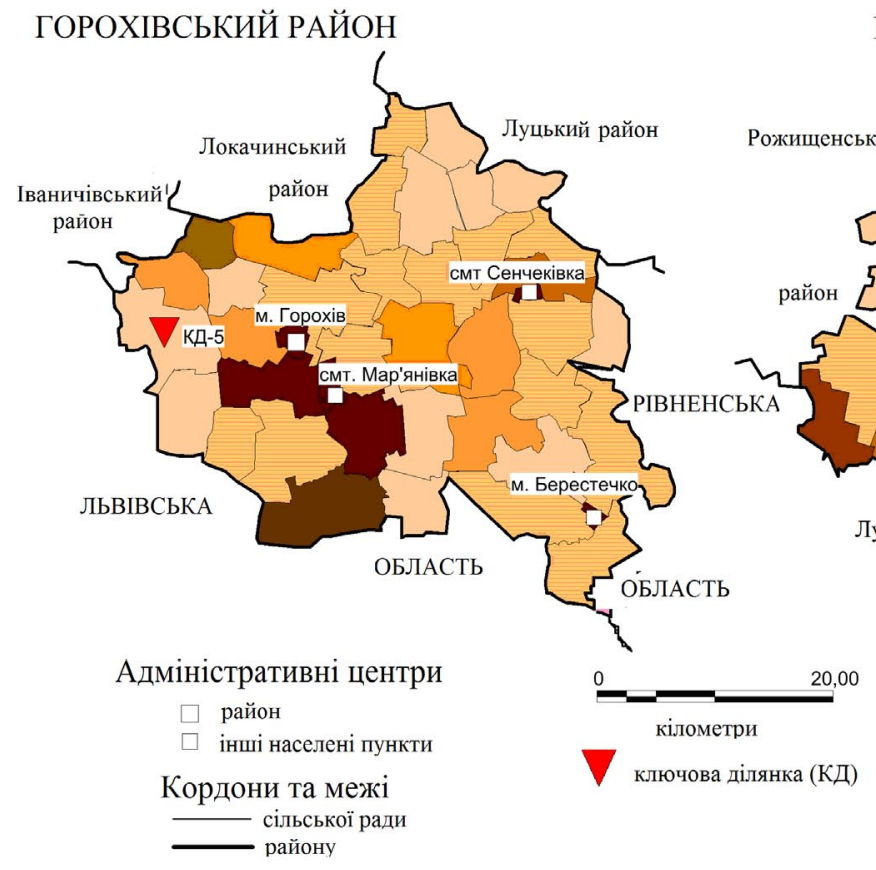

КІВЕРЦІВСЬКИЙ РАЙОН

КОРЦВСБКИЙ РАЙОН

Маневицький район
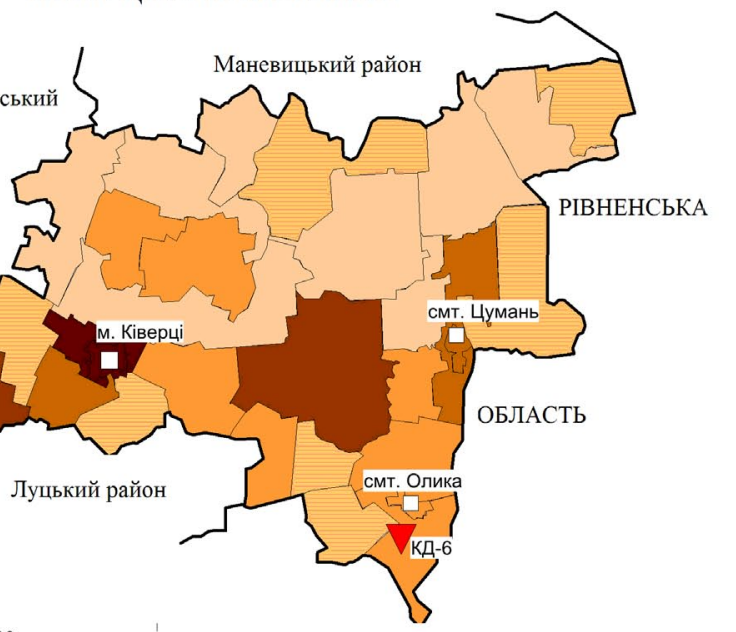

Частка забудованих земель від загальної плоші. \%

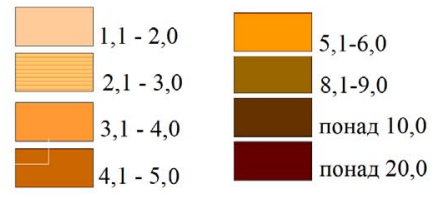

Рис. 3. Забудованість височинної території Волинської області

Територія височинної частини Волинської області характеризується значними відмінностями показника забудови від 1,66 \% (КД-5) до 4,61 \% (КД-6). Разом із тим відмічаємо, що для окремих територій сільських ландшафтного рисунка, транспортної, обслуговувальної інфраструктури.

Для аналізу структури селитебно-забудованих ландшафтів ми використали матричний підхід 
Показники характеристики селитебної забудованості височинної території Волинської області

\begin{tabular}{|c|c|c|c|c|c|}
\hline \multirow[t]{2}{*}{ Адміністративна одиниця } & \multirow{2}{*}{$\begin{array}{c}\text { Усього земель } \\
\text { га }\end{array}$} & \multicolumn{2}{|c|}{ Забудованість території } & \multicolumn{2}{|c|}{$\begin{array}{c}\text { Селитебно-житлова } \\
\text { забудова }\end{array}$} \\
\hline & & га & $\%$ & га & $\%$ \\
\hline Волинська обл. & 2014400 & 60700,0 & 3 & 11600,0 & 19,1 \\
\hline Горохівський р-н & 112217,0 & 4666,8 & 4,1 & 113,4 & 3,2 \\
\hline $\begin{array}{l}\text { Ключова ділянка № } 5 \\
\text { (Печихвостівська с/p) }\end{array}$ & 4656,0 & 77,3 & 1,66 & 10,7 & 13,0 \\
\hline Ківерцівський р-н & 141426,0 & 4762,3 & 3,36 & 778,2 & 16,34 \\
\hline $\begin{array}{l}\text { Ключова ділянка № } 6 \\
\text { (Олицька с/p) }\end{array}$ & 4009,59 & 185,21 & 4,61 & 64,0 & 34,55 \\
\hline
\end{tabular}

Г. Ріхтера (Rudenko,1999). Цілісна матрична система складає 100 \% території забудованих земель. Побудовані матриці відображають співвідношення площі комплексів використання селитебно-забудова- них ландшафтів та співвідношення площі забудови у масштабі для території досліджуваних районів: Горохівського та Ківерцівського (рис. 4).

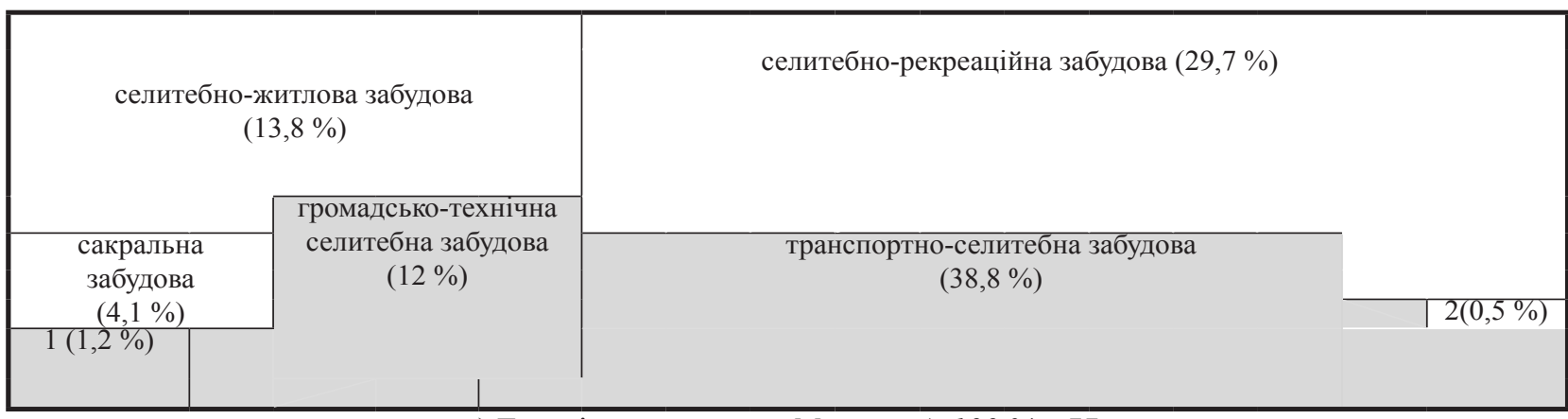

а) Горохівський район. Масштаб: $100 \%=77$ га.

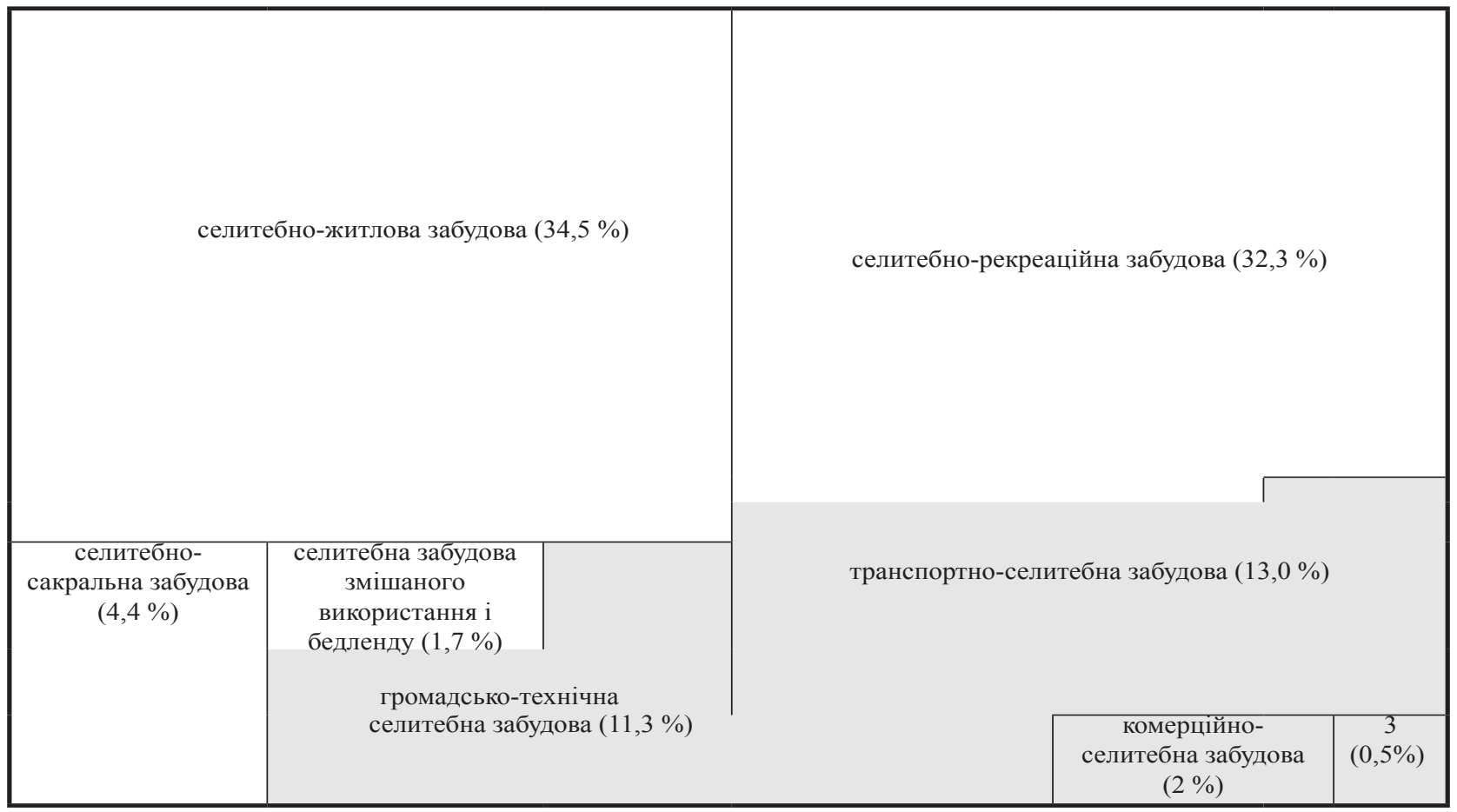

б) Ківерцівський район. Масштаб: $100 \%=185$ га.

Рис. 4. Матриця використання селитебно-забудованих ландшафтів та їх співвідношення:

1 - комериійно-селитебна забудова; 2 - селитебна забудова зміманого використання і бедленду;

3 - промислово-селитебна забудова;

$\square$ - селитебна інфраструктура 
Так, у структурі забудови Горохівського району відмічаємо переважання частки транспортноселитебної забудови $(38,8$ \%). На другій позиції розташовані землі, зайняті селитебно-рекреаційними ландшафтами (29,7 \%). На забудову селитебно-житлового типу припадає $13,8 \%$. Найменшу частку займають землі комерційного $(1,2 \%)$ та змішаного використання $(0,5 \%)$ (рис. $4 \mathrm{a})$.

Для забудови у Ківерцівському районі характерне домінування частки селитебно-житлової $(34,5$ \%) та селитебно-рекреаційної забудови (32,3\%). Частка землі транспорно-селитебної забудови становить $13 \%$, громадсько-технічної - 11,3\%. Найменша частка припадає на землі промислово-селитебної забудови (рис. 4б).

Горизонтальна структура забудованих земель на ключових ділянках відображена в таблиці. 2. У межах КД-5 найбільшу площу займають землі, зайняті об'єктами транспорту та зв'язку - 30 га (38,8 \%), на другій позиції землі рекреаційного використання - 23,0 га $(29,75 \%)$ та території під житловою забудовою - 10,7 га (13,8 \%). Найменшу площу займають землі комерційної забудови 1,0 га (1,29\%). відображення в зміні ландшафтного рисунка. Аналіз топографічних карт різних часових зрізів (1975 -1988 pp., 1933 р., 1910 р.) та сучасних космічних знімків (2014 р.) території підтверджує активний розвиток селитебного ландшафту.

На основі опрацювання картографічних джерел ми побудували цифрову векторну модель динаміки селитебної забудови. На цифровій моделі відображена територія с. Мишів, розташованого в межах КД-5.

Відмічаємо не тільки зміну площі селитебного ландшафту, а й відмінності власне контуру ландшафтного рисунка, що відбувались протягом століття (рис. 5).

Рисунок сучасного селитебного ландшафту Волинської височини початку XXI ст. (с. Мишів) відрізняється від рисунка початку XX ст. збільшенням площі просторової орієнтації рисунка ландшафту. Один із провідних чинників формування сучасного рисунка - це розвиток транспортної інфраструктури, а також види промислового та сільськогосподарського природокористування, тому селитебний ландшафт характеризується квартальною забудовою.

Очевидно, відмінності, які спостерігаємо у період

Структура селитебно-забудованих земель височинної території Волинської області

Таблиия 2

\begin{tabular}{|c|c|c|c|c|c|}
\hline \multirow{2}{*}{\multicolumn{2}{|c|}{ Селитебно-забудовані землі }} & \multicolumn{2}{|c|}{ КД-5 } & \multicolumn{2}{|c|}{ КД-6 } \\
\hline & & га & $\%$ & га & $\%$ \\
\hline \multirow{10}{*}{ 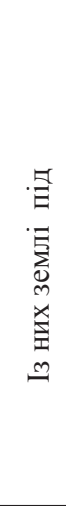 } & житловою забудовою & 10,7 & 13,84 & 64,0 & 34,55 \\
\hline & промисловими об’єктами & - & - & 0,92 & 0,49 \\
\hline & $\begin{array}{l}\text { відкритими розробками, кар'єрами шахтами та } \\
\text { відповідними спорудами }\end{array}$ & - & - & - & - \\
\hline & комерційною забудовою & 1,0 & 1,29 & 3,65 & 1,97 \\
\hline & громадською забудовою & 9,4 & 12,16 & 21,03 & 11,35 \\
\hline & змішаного використання & - & - & - & - \\
\hline & транспортною забудовою & 30,0 & 38,8 & 24,1 & 13,01 \\
\hline & технічною інфраструктурою & - & - & 3,31 & 1,78 \\
\hline & рекреаційного використання & 23,0 & 29,75 & 60,0 & 32,39 \\
\hline & кладовища & 3,2 & 4,1 & 8,2 & 4,42 \\
\hline \multicolumn{2}{|c|}{ усього } & 77,3 & 1,66 & 185,21 & 4,61 \\
\hline & Загальна площа земель & \multicolumn{2}{|c|}{4656,0} & \multicolumn{2}{|c|}{4009,59} \\
\hline
\end{tabular}

Структура забудованих земель у межах КД-6 характеризується збільшенням частки селитебнорекреаційної забудови (зелені насадження загального використання - 9 га та землі вулиць, набережних, площ - 36 га), та зменшенням територій з транспортною інфраструктурою (13,01\%), а селитебножитлова забудова посідає перше місце у структурі забудованих земель $(34,5$ \%).

Площа забудованих земель ускладнює сучасну ландшафтну структуру області і знаходить з 1975 р. по 1988 р., порівняно з 1933 р. зумовлені ліквідацією хутірської мережі поселень, що була характерна для території Волині на початку XX століття (Nychaja, 2015).

У структурі селитебно-забудованих земель провідне місце займають площі під житловою забудовою. Побудовані картосхеми відображають частку селитебно-житлової забудови в загальній площі забудованих земель (рис. 6). 


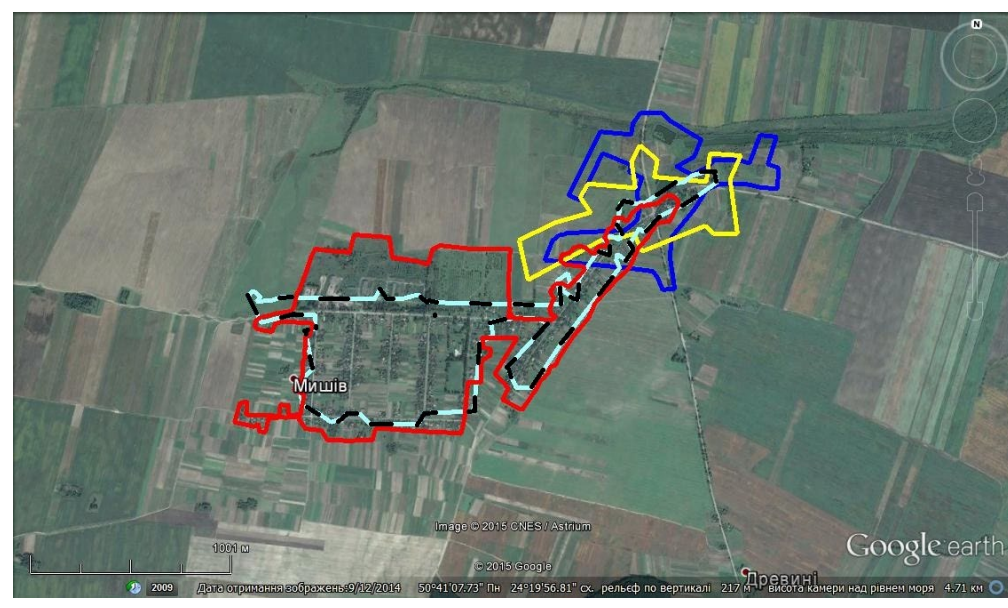

Найнижчий показник селитебно-житлової забудови в межах Цегівської (1,7 \%), Перемильської $(2,3 \%)$, Лемешівської $(2,3 \%)$ c/p у Горохівському районі та Озерської (5,3\%), Журавичівської (6,2 \%), Дернівської (8,2 \%) c/p Ківерцівського району. Найвищий показник частки житлової забудови характерний для міських рад - Берестецької (49,9%), Горохівської $(33,6$ \%) та Ківерцівської міської ради (35,6 \%). Багатоповерхова забудова (вертикальна структура) в межах височинної території Волинської області властива лише для міських селитебних ландшафтів (або урболандшафтів).

Висновки та перспективи подальших досліджень. У результаті проведеного аналізу встановлено, що в

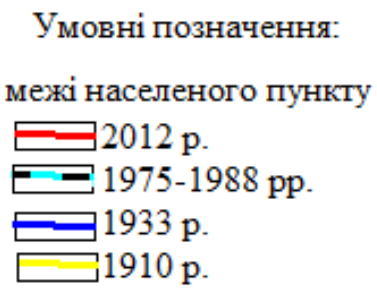

Рис. 5. Цифрова векторна модель динаміки селитебної забудови с. Мишів Печихвостівської сільради
УМОВНІ ПОЗНАЧЕННЯ:
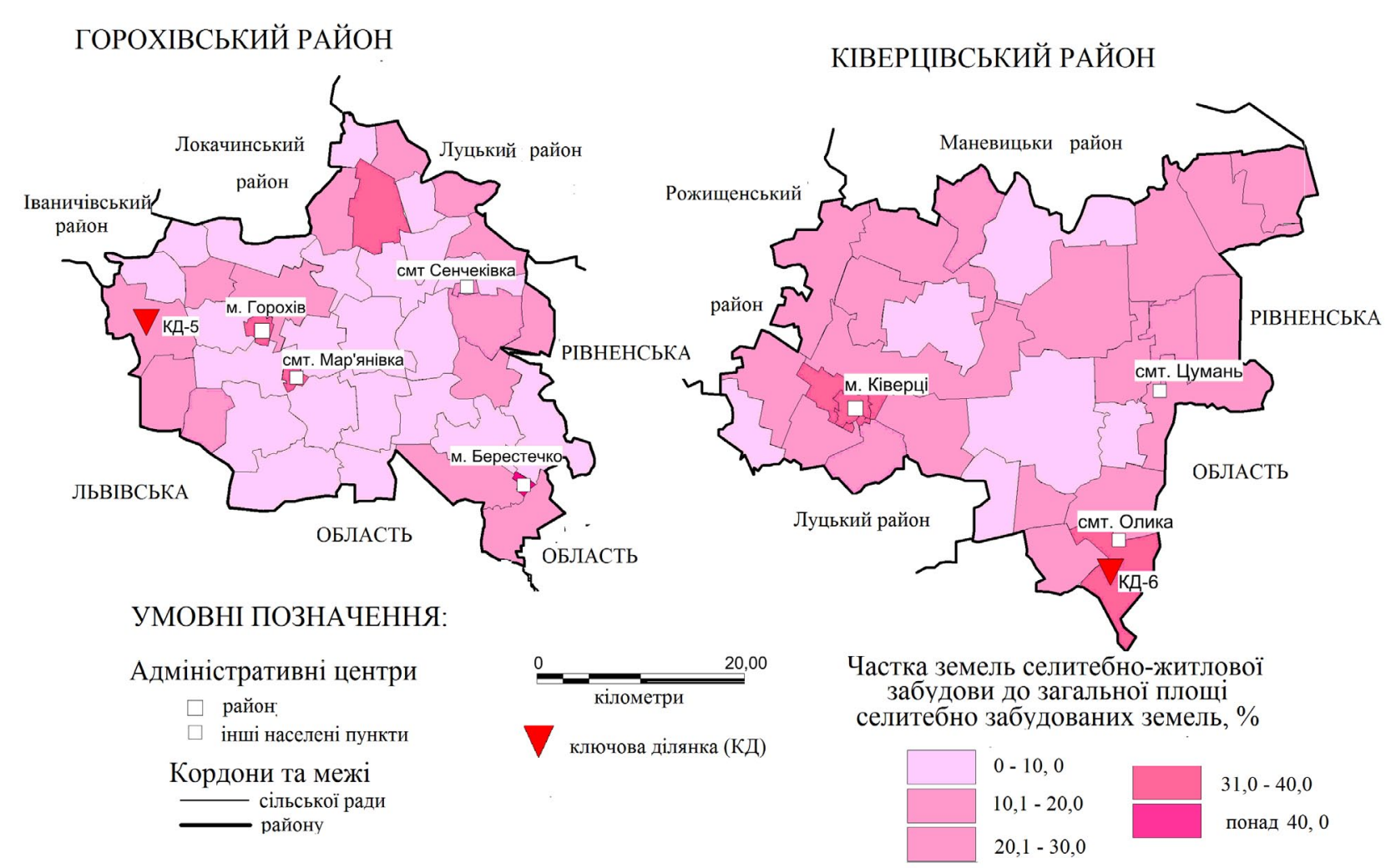

межах височинної території Волинської області частка забудованих земель становить 4,1% (Горохівський район) та 4,6 \% (Ківерцівський район). Цей показник вищий середнього показника по області (3 \%). Площа селитебно-забудованих земель збільшується впродовж останнього століття і це знаходить відображення у ландшафтній структурі, зміни характерні і для рисунка ландшафту, його конфігурації та орієнтації. Такий підхід до вивчення забудованих земель дає можливість оптимізувати їх використання для потреб районного планування. Подальші дослідження з урахуванням аналізу динаміки зміни площ забудованих земель та особливостей планувальної структури населених пунктів з використанням сучасних технічних можли-

Рис. 6. Частка селитебно-житлової забудови від загальної площі забудованих земель височинної території Волинської області 
востей один із пріоритетних напрямів забезпечення геоекологічної реабілітації селитебних ландшафтів для потреб регіонального розвитку.

\section{Бібліографічні посилання}

Darchuk, K. V. 2011. Suchasnyj stan vykorystannja zabudovanyh zemel' Ivano-Frankivs'koi' oblasti. [Modern state of the use of built-up earths of the Ivano-Francovsk area]. The Scientific Notes of Ternopil Volodymyr Hnatiuk National Pedagogical University. Series: Geography. 696, 86-91. (in Ukraiane).

Denysyk, G. I. 1998. Antropogenni landshafty Pravoberezhnoi' Ukrai'ny. [Anthropogenic landscapes of Right-bank Ukraine]. Arbat, Vinnycja. (in Ukraiane).

Litynskyj, V. 2001. Geodezychnyj encyklopedychnyj slovnyk [Geodesic Encyclopedic Dictionary]. Lviv. (in Ukraiane).

Malchykova, D. S. 2010. Vykorystannja GIS/DZZ-tehnologij dlja vyvchennja terytorial'noi' struktury zemlekorystuvannja regionu. [GIS/RS_technologies of the study of land use territorial structure of region]. Periodic publication. Problems without interruptions geographical education and Cartography. 12, Herson. 123-128. (in Ukraiane).

Kovalchuk, I. P., Martyn, A. G., Jevsjukov, T. O., Tyhenko, R. V., Bogdanec, V. A., Zhuk. O. P., Openko, I. A. 2015. Konceptual'ni zasady vyrishennja problem zemleustroju sil's'kyh terytorij v suchasnyh umovah: monografija. [Conceptual Foundations of problems rural land management in modern conditions]. Medinform. Kiev. (in Ukraiane).

Nychaja, O. O. 2015. Retrospektyvno-geografichnyj analiz zabudovy jak vydu pryrodokorystuvannja na terytorii' Volyns'koi' vysochyny (v mezhah Volyns'koh oblasti). [Retrospective and geographical analysis of buildings as a form NATURE IN Volyn Upland (within Volyn region)]. Actual questions of contemporary science. Herson. Ch. II. 20-22. (in Ukraiane).

Pavlovska, T. S. 2014. Struktura zemel'nyh ugid' v landshaftnoekologichnij organizacii' terytorii' Volyns'koi' oblasti
[The structure of the lands in landscape-ecological organization of territory of the Volyn region]. Geopolitics and Ecogeodynamics regions. Science Magazine. Symferopol.10, 697-704. (in Ukrainian).

Ryhter, G. 1983. Kul'tura landshafta v socyalystycheskom obshhestve. [A culture of landscape is in socialistic society]. Progress. Moskva. (in Russian).

Rudenko, V. P. 1999. Geografija pryrodno-resursnogo potencialu Ukrainy. [Geography natural resource potential of Ukraine]. «K. - M. Akademija». Kiev. (in Ukrainian).

Suhyj, P. O. 2007. Osoblyvosti suchasnogo rozpodilu ta vykorystannja zemel' sil's'kogospodars'kogo pryznachennja v oblastjah Zahidnoi' Ukrai'ny. [Features modern distribution and use of agricultural land in the regions of Western Ukraine]. The Scientific Notes of Ternopil Volodymyr Hnatiuk National Pedagogical University. Series: Geography. 2, Ternopil. 84-90. (in Ukrainian).

Tarasjuk, N. A., Nychaja, O. O. 2015. Geografichna ocinka suchasnogo stanu vykorystannja zabudovanyh zemel' terytorii' Polissja (na prykladi Volyns'koi' oblasti). [The Geographical Assessment of the Current Condition of the Built-Up Land Use in the Territory of Polissia (Volyn region)]. The Scientific Notes of Ternopil Volodymyr Hnatiuk National Pedagogical University. Series: Geography. 2. SMP “Tajp”. Ternopil. 200-208. (in Ukrainian).

Shvorak, A. V. 2001. Osoblyvosti zemlevporjadkuvannja terytorii' sil's'koi' (selyshhnoi') rady. [Features of land the village council]. Zemlevporjadkuvannja. 4, 25-28. (in Ukrainian).

Tarasiuk, N., Nychaja, O. O. 2014. GIS of regional geography in the study of present landscapes. Materiały konferencyjne GIS DZIŚ. Krakow. 73-75. (in Poland).

Golovne upravlinnja Derzhgeokadastru u Volyns'kij oblasti. (2016, February 01) Retrieved from http://zem.voladm. gov.ua.

Google earth. (2015, November 01) Retrieved from http:// www.google.com.ua/intl/ru/earth. 